\title{
The role of metabolomics in osteoarthritis for early diagnosis, monitoring prognosis and treatment
}

\author{
Metabolomiklerin osteoartritte erken tanı, prognoz ve tedavinin izlenmesindeki rolü
}

\author{
O. Şahap Atik, MD. \\ Department of Orthopedics and Traumatology, Medical Faculty of Gazi University, Ankara, Turkey
}

Osteoarthritis (OA) results from a complex system of interacting mechanical, biological, biochemical, molecular, and enzymatic factors. ${ }^{[1-3]}$

The early stages of OA may remain latent and asymptomatic for many years. Therefore, radiographic method is not suitable for early diagnosis. The use of quantitative magnetic resonance imaging (MRI) to assess changes in cartilage volume or thickness is promising. However, widespread use of MRI is limited by cost.

Metabolomics is the analysis of small molecules in urine, serum, synovium, and synovial fluid. It has led to identifying novel biomarkers for diagnosis, monitoring prognosis and treatment of several diseases including OA. ${ }^{[4]}$

Most of the biomarkers related to collagen metabolism in cartilage are significantly different from controls in OA patients. ${ }^{[5]}$ Urinary C-terminal telopeptide of collagen type II (CTX-II) is a good example.

Omics-based technologies including genomics, transcriptomics, proteomics, metabolomics, glycomics etc. can be applied to the evaluation of cartilage, synovium, synovial fluid, serum or urine from OA patients. The combinations of existing and new biomarkers may improve their prognostic accuracy and help identify at-risk patients. ${ }^{[6]}$

Finally, there is a potential role of biomarkers in the research for pathogenesis of $\mathrm{OA}$ and the development for discovery of new molecules for the treatment of OA.

\section{REFERENCES}

1. Martel-Pelletier J, Pelletier JP. Is osteoarthritis a disease involving only cartilage or other articular tissues? Eklem Hastalik Cerrahisi 2010;21:2-14.

2. Sahap Atik O. Leukotriene B4 and prostaglandin E2-like activity in synovial fluid in osteoarthritis. Prostaglandins Leukot Essent Fatty Acids 1990;39:253-4.

3. Atik OŞ, Tokgöz N. Do periarticular dense bone islands cause cartilage destruction? Eklem Hastalik Cerrahisi 2013;24:39-40.

4. Adams SB Jr, Setton LA, Nettles DL. The role of metabolomics in osteoarthritis research. J Am Acad Orthop Surg 2013;21:63-4.

5. Lotz M, Martel-Pelletier J, Christiansen C, Brandi ML, Bruyère $\mathrm{O}$, Chapurlat $\mathrm{R}$, et al. Value of biomarkers in osteoarthritis: current status and perspectives.Ann Rheum Dis 2013;72:1756-63.

6. Williams FM. Biomarkers: in combination they may do better. Arthritis Res Ther 2009;11:130.

\footnotetext{
- Correspondence: O. Şahap Atik, MD. Gazi Üniversitesi Tıp Fakültesi Ortopedi ve Travmatoloji Anabilim Dalı, 06500 Beşevler, Ankara, Turkey Tel: +90 312 - 2025528 Fax: +90 312 - 2129008 e-mail: satikmd@gmail.com
} 